Olga Shalamai, Master in International Management, Rawdat Al-Ma'aref Schools and College (Amman, Jordan)

\title{
FREE TRADE ZONE AND THEIR ROLE IN ECONOMIC DEVELOPMENT (COMPARATIVE ANALYSIS OF THE UKRAINIAN AND JORDANIAN EXPERIENCE)
}

\begin{abstract}
This article is devoted to a comparative analysis of the functioning of special economic zones in Aqaba, Hashemite Kingdom of Jordan, and Ukraine. The work gives the concept and classification of the Free trade zones (FTZ), reflects the goals of creating zones and their purpose. The main goal of the work is to study the features of FTZs in Jordan and Ukraine and determine what experience Ukraine can gain from Jordan to optimize the work of the Ukrainian FTZs. During the research we grounded that Ukraine has essential resource opportunities, such as: natural resources, working capital, and geographical location compared to Jordan, which despite of all the obstacles could implement ASEZ and gradually improve its economy. Jordanian experience proves that the desire of a strong Leader and his loyal team, despite of the concentration of hot points all around the borders, unstable political relationship with its neighbors, high refugees inflow definitely led to the deterioration of economic situation in the country. A large stock of foreign debt, insufficient supplies of water, oil, and other natural resources, high level of unemployment - succeeded in its effective implementation of ASEZ and overcame all the severities. Thus, hopefully this research might inspire the Ukrainian leaders to promote the development of Ukrainian FTZs in order to prosper our economy and improve the standard of living.
\end{abstract}

Keywords: free trade zone, contemporary economics, development, international economics, Jordan, Ukraine

1. Introduction. The beginning of the $21^{\text {st }}$ century is characterized by a boom in Free Trade Zones (FTZ) in the world economy [11]. This is confirmed by the fact that even such small counties, as for example, Myanmar and Rwanda, are going to create FTZ's for the first time in their territory. But countries where FTZs have already been in existence for a long time such as China, the UAE, the Philippines, and South Korea plan to double their number in the coming years. The reason for the begun hype is quite clear. FTZs can increase export 
potential and form a market infrastructure, intensify entrepreneurship and accelerate the development of individual regions and sectors of the economy [3;20].

The relevance of this topic concludes in the fact that in the context of growing competition in the global economy, free trade zones contribute to growth [12]. The economy is not in the export and import of products, but also in the creation of production complexes and innovative development sectors. The objective of the article is to determine the goals of creating FTZs, present their classification, consider the experience of Jordan in the formation of FTZ and reveal the problems of the development of zones in Ukraine.

Free Trade Zone, known as FTZ, is a geographic area where goods may be landed, stored, handled, manufactured, and re-exported under specific customs regulation where normal trade barriers like quotas, tariffs are removed and the bureaucratic necessities are narrowed. FTZ's are located in the developing countries where they can attract new businesses and foreign investment and to develop the economy of that location by providing more job opportunities, business options, manufacturing options, etc. in order to stimulate economic growth. FTZs are often found throughout the world as the major seaports, international airports, and other locations with strong transportation ties [2;7].

In the condition of economic crisis, the breakdown of the traditional economic ties, and the reduction of capital investments at the critical level of physical and moral depreciation of fixed assets, the creation of Free Trade Zones in Ukraine is considered as one of the priority means for the rapid solution of many problems. Moreover, a limited number of resources causes the development of investment programs, the implementation of which requires an appropriate selection of territories with the most favorable conditions. In this sense, due to the concentration of funds, FTZs can play the role of growth centers, which can initiate the revitalization of the country's economy as a whole in the future.

Ukraine has good natural, geographic and economic preconditions for the creation of the Free Trade Zone. It has an advantageous geographical location, due to its proximity to world markets, in particular European markets (including Central and Western European ones), to significant suppliers of raw materials, a developed system of communication transport and substantial own of natural wealth. In addition, Ukraine has an outstanding labor, scientific and technical potential. Thus, there are many factors that are favorable for foreign investors and for the development of international cooperation.

FTZs can become a real epicenter of the technological breakthrough of Ukraine to a new, modern level of production of competitive goods. This can contribute to its participation in the international division of labor as a manufacturer of high-tech products, as Ukraine has 
wide opportunities for the creation of FTZs of technical implementation, in particular, in such research centers as Kiev, Kharkiv, Dnipro, Lviv and Odessa. The distinctive feature of this type of FTZ's is that the purpose of their creation is to mobilize all available material and labor resources to accelerate the transfer of new high technologies to industry. In addition, The Carpathian, Vinnytsya, Odessa and Poltava - have a significant prospect for the development of the Free Trade Zone, primarily - recreational.

Following the example of the Aqaba's FTZ, Ukraine could also build up its economy despite of the high unemployment, large stock of foreign debt, the war on the Eastern part of Ukraine or even occupation in Crimea. In May 2001 according to the Aqaba Special Economic Zone Law No. 32 ASEZ was established and began to function. Covering the Kingdom's seaport of Aqaba and its environs, including Wadi Rum, the zone was established on $375 \mathrm{sq} \mathrm{km}$ of territory in the south of Jordan within the population of about $90,000^{1}$.

The Cabinet appointed a six-member Commission, headed by a Chief Commissioner to form the board of the Aqaba Special Economic Zone Authority (the ASEZA). The Commission has the task of running the ASEZ, and is vested with zoning, licensing, and other regulatory powers [13].

The ASEZ has a special fiscal regime, like absence of customs duties on imports into the Zone, social service tax, annual land and property taxes. It has a 5 present tax rate applied on all net business income (in contrast with a 35 percent rate for other parts of the country), except that from banking, insurance and land transport activities. A 7 percent sales tax is limited to the consumption of selected personal goods and hotel/restaurant services (as opposed to a 13 percent levy for other parts of the country).

The ASEZA's declared a mission to improve the quality of life for all community members; to create, regulate and sustain a globally competitive investor-friendly environment; to optimize the efficient utilization of entrusted resources in harmony with a master plan to internationally recognized best practices; and effective, transparent and accountable corporate structure, governance, and culture that synergize the activities of the organization [21].

In Ukraine, a certain legal basis has already been established for the functioning of the Free Trade Zones. This is primarily the Law of Ukraine "On the General Principles of the

\footnotetext{
${ }^{1}$ According to Article 4 of the ASEZ Law, "The perimeters of the Zone shall be determined by a decision of the Cabinet upon the recommendation of the [ASEZA] Board. The Cabinet may amend these perimeters according to the business requirements of the [ASEZ] Authority and the exigencies of public interest". For our purposes, it is important to note that, though these perimeters have been fixed since the project was launched, they were the subject of some previous debate and may now also possibly be subject to change.
} 
Establishment and Functioning of Special (Free) Economic Zones", adopted in 1992. In 1994, the Government approved the "Concept for the creation of special (free) economic zones in Ukraine", and in 2000 - Regulation on the criteria for determining the priority types of economic activity in the special (free) economic zones and territories with a special regime of investment activity and the procedure for their application ". During the 1990's, the Cabinet of Ministers of Ukraine received about 100 proposals on the establishment of free economic zones. Attempts to create FTZs were made in Zakarpatti, Polissya, Crimea, Odessa, Dnipro, Donetsk, Mykolaiv and other regions of Ukraine. However, until recently, only the northCrimean experimental economic zone "Sivash" was functioning in Ukraine - a local economic experiment on the territory of Krasnoperekopsky district and the city of Armenian in the Crimea of course before annexation. FTZ "Sivash" belonged to zones of industrial character. It was aimed at revitalizing small and medium-sized businesses in a depressed region by creating favorable conditions for free trade and economic activity and providing incentives for new productions.

The Verkhovna Rada of Ukraine adopted the decision on the formation of the FTZ "Sivash" in March 1996. FTZ specialized in the production of exportable chemical products. There were such unique companies as the Crimean "Titan", Sivash aniline-paint, Crimean soda and Perekop bromine plants, as well as the processing plant for recycled polymeric materials "Polivtor", which accounted for 70 to $90 \%$ of the local budget before annexation. Thanks to the creation of this FTZs managed to save about 2.5 thousand jobs and created hundreds of new ones. During the two years of work (since 1997), 11 subjects of the FTZ have been registered. In total, more than 60 investment applications were submitted, including entrepreneurs from England, Germany, Turkey, Sweden, the USA, Slovakia and the Netherlands. It was at the expense of preferential taxation of subjects of FTZ that formed the initial capital for the development of the infrastructure of the zone.

2. Background to the reform (for Jordan). Despite of the large stock of foreign debt, high unemployment, and a lot of the population living below the poverty line, Jordan has for the 20 years struggled to achieve expansion of GDP greater than population growth [10]. The same as Ukraine, The Kingdom in the second half of the 1990s suffered from a weak economic performance as a series of wide-ranging structural reforms were implemented and GDP growth barely averaged 3 percent. As the same period witnessed more than 3 percent annual population growth, real per capita GDP stagnated. Currently Jordan's economy is among the smallest in the Middle East, with insufficient supplies of water, oil, 
and other natural resources underlying the government's heavy reliance on foreign assistance. Other economic challenges for the government include chronic high rates of poverty, unemployment, inflation, and a large budget deficit [23]. Since assuming the throne in 1999, King ABDULLAH has implemented significant economic reforms, such as opening the trade regime, privatizing state-owned companies, and eliminating some fuel subsidies, which in the last decade spurred economic growth by attracting foreign investment and creating some jobs. The global economic slowdown and regional turmoil, however, have depressed Jordan's GDP growth impacting export-oriented sectors, construction, and tourism. Jordan's finances have also been strained by a series of natural gas pipeline attacks in Egypt, causing Jordan to substitute more expensive diesel imports, primarily from Saudi Arabia, to generate electricity $[14 ; 17]$. Jordan is currently exploring nuclear power generation in addition to the exploitation of abundant oil share reserves and renewable technologies to forestall energy shortfalls. To correct budgetary and balance of payment imbalance, Jordan entered into a $\$ 2.1$ billion, multiple year International Monetary Stand-By Arrangement. Jordan's financial sector has been relatively isolated from the international financial crisis because of its limited exposure to overseas capital markets. In 2013, Jordan depended heavily on foreign assistance to finance the budget deficit, as the influx of about 600,000 Syrian refugees put additional pressure on expenditures. Currently Jordanian economy according to the World Bank's main economic indicators (Table 1) has improved gradually: GDP per Capita since 2016 has increased by $0,5 \%$, General Government Balance has an impressive progress from - 3.0 in 2016 to 0.3 by April 2019, general Government Debt has decreased by $2.5 \%$.

\section{Table 1}

Macroeconomic Characteristic of Jordan

\begin{tabular}{|c|c|c|c|c|}
\hline Main Indicators & $\mathbf{2 0 1 6}$ & $\mathbf{2 0 1 7}$ & $\mathbf{2 0 1 8}(\mathbf{e})$ & $\mathbf{2 0 1 9}(\mathbf{e})$ \\
\hline GDP (billions USD) & 38.71 & $40.13 \mathrm{e}$ & $41.87 \mathrm{e}$ & 43.99 \\
\hline $\begin{array}{c}\text { GDP (Constant Prices, Annual } \\
\text { \% Change) }\end{array}$ & 2.0 & $2.0 \mathrm{e}$ & 2.3 & 2.5 \\
\hline $\begin{array}{c}\text { GDP per Capita (USD) } \\
\text { General Government Balance } \\
\text { (in \% of GDP) }\end{array}$ & $4,094 \mathrm{e}$ & $4,136 \mathrm{e}$ & 4,228 & 4,368 \\
\hline $\begin{array}{c}\text { General Government Gross } \\
\text { Debt (in \% of GDP) }\end{array}$ & -3.0 & -1.3 & -0.9 & 0.3 \\
\hline Inflation rate (\%) & 95.073 & 95.855 & 95.966 & 95.052 \\
\hline Current Account (billions USD) & -0.8 & 3.3 & 4.5 & 2.3 \\
\hline Current Account (in \% of GDP) & -9.5 & -4.26 & -4.03 & -3.80 \\
\hline
\end{tabular}

Source: [15 16;23] 
The past few years have witnessed an increasing recognition of the need to move economic policy away from pre-occupation with macro-economic stabilization embodied in the successive structural adjustment programs, to an explicit growth orientation. To make the Jordanian economy move ahead substantially, the slight increase in a growth rate is required to create new employment opportunities and absorb part of the unemployed. The state will have to play a stronger role in helping to improve the situation in the labor market. The situation in the labor market remains problematic, with the most worrying feature the inability of the economy to develop fast enough to provide employment for young people. Related to this problem of labor force restructuring is the issue of regional development, thus the Jordanian government has been busy for the last few years investing in the development of the south of the country, with the designation of the city of Aqaba and its environs as a special economic zone.

The position of Aqaba in the Jordanian and regional economies. Tourism, transport and certain kinds of industry could be important for Aqaba, partly thanks to the city's location and the natural endowments of its hinterland. The city of Aqaba and its hinterland also have the potential to attract a wide range of business. At the same time Aqaba and Jordan's strategy to attract international investments is vulnerable to events in Palestine and Iraq [4].

During the Iran-Iraq War, Aqaba became an indispensable part of Iraq's supply line [19]. By early 1981 Jordan had become the main supply route for war material and civil goods destined to Iraq. In addition to the Jordanian-Iraqi connection, Aqaba had also become a key transit point for war material going from Egypt to Iraq, and for Egyptian workers going to and from Jordan and Iraq. However, the second Gulf War and the imposition of UN sanctions against Iraq, curtailed the utility of Aqaba as a regional seaport. Aqaba then faced stiff competition from Latakia, Beirut and Dubai. The port, which employed around 5,000 workers, was by the late 1990s underutilized, handling 12.5 million tons of goods each year, whereas its annual capacity was estimated at 30 million tons per annum.) [1;9]

Jordan's only seaport generally suffers from state control, though some in the United Arab Emirates (UAE) and a few other places have managed to reduce government intervention. Most MENA ports including Aqaba are intended to and actually serve as a source of government revenue and employment.

Background for reform (Ukraine). Unfortunately, today it is not used in full and it is not advantageous from the point of view of transportation, economic and the geographical location of Ukraine. Therefore, in the future, experts recommend the decision on the creation 
of foreign trade zones to consider in conjunction with issues on the development of international transport corridors. The Baltic-Black Sea Transport Corridor and the Euro-Asian Transport Corridor should attract powerful transit flows into Ukraine, including South-East Asia and Africa with Europe, the Middle East to Europe, Central Asia and Europe, and create one of the most promising transport arteries for Ukraine intercontinental value. As part of these corridors potentially there may be several free zones. In particular, this concerns the Interport-Kovel FTZ in the Volyn region, the interstate FTZ "Renji Galati-Giurgiulesti", the FTZ "Porto-Franco" in Odessa, the FTZ "Adjalyk" and the FTZ "Antarctica" in Ilichevsk.

Thus, the special economic zone "Interport-Kovel" is called a new center for Eastern Europe. Cargos from all over Europe will go through the transport and warehouse center of this "port" on land. The center will carry out their complex processing, transshipment from one type of transport to another, including the transition from narrow European railway tracks to broad domestic ones. In addition, it will organize the storage of goods and perform many other services. "Interport" has no analogues in the CIS countries.

At the end of 1998 a decree was issued by the President of Ukraine on the creation of an FTZ in the Renaissance trading port, which should become the first stage of the formation of the international special economic zone "Renigalatz - Giurgiulesti". The Renaissance maritime trading port is at the crossroads of four transport corridors: Nos 7 and 9 for the Cretan EU agreements, as well as global corridors - the Black Sea Economic Cooperation (BSEC) and the Euro-Asian Transport and Communications Corridor. Already today, it has direct connection with 14 European countries, the list of which can quickly expand beyond Europe due to direct access to the Black Sea, as well as other water areas. These peculiarities are due to the active interest in the region in the triangle of Reni (Ukraine) - Galati (Romania) - Giurgiulesti (Republic of Moldova) from the three neighboring states. At the same time, each of them has a kind of "keys" to the region. Ukraine controls the port, Romania - Canal Danube - Black Sea, Moldova - railway accesses. Given the special international transport and communications status of this region, the governments of Romania and Moldova have long been active in their own right. This, in particular, indicates Moldova's intention to build its oil terminal in order not to be directly connected with the Rhine port.

Several free zones can be located within the EU transport corridors Nos. 3, 5, 7, 9. In particular, this FEZ "Mostiska", FEZ "Zhovkva", FEZ "Yavorov "in the Lviv region, FEZ "Transcarpathia" and others. According to preliminary estimates, the potential to attract additional international traffic flows is quite large. The volume of these transportations in the near future can be increased by $25-30 \%$, and in the future, with the provision of sufficient and 
high-quality services and bringing the transport infrastructure in line with international requirements, transportation can be increased several times. Accordingly, foreign exchange revenues to the state and local budgets will increase, the amount of which, according to experts, can reach several billion US dollars.

3. Analysis and description of the ASEZ. In February 1999, King Abdullah ascended the throne and the same year the new Cabinet decided major institutional changes for Aqaba. King Abdullah supported the creation of the Economic Consultative Council (ECC) to monitor the implementation of vital socio-economic, administrative and educational reforms. The ECC was noteworthy for two things: the young technocrats from the private sector who were among its members, some of whom would soon become ministers and key ambassadors, and the fact that a new body appointed by the king and personally supervised by him was charged with this massive task of national economic transformation, rather than existing institutions of the state, such as parliament and the cabinet. In fact, the ECC undertook the final stage of work on the ASEZ [5]. In April 2000 the project to turn Aqaba into a special economic zone was about completely transforming the city, including its administrative system and institutions. The plan promised to radically change the coast. The cabinet would retain the power to approve the budget for Aqaba, and set the regulations and by-laws for the sale of land (for housing, offices, and small hotels) and the leasing of land (for warehouses, factories and large hotels [22]). Plans were also being drawn to move the port's then present location and move the airport $15 \mathrm{~km}$ north of its present location. The transport revolution in Aqaba also included building a new road behind the mountains for trucks to relieve pressure on the coastal road that was used solely for tourist transport as a "scenic road". The railway was extended to reach the port in the planned "heavy industrial area" and to handle all potash transport, possibly also from Israel, with a possibly of connecting the railroad to the Mediterranean in the more distant future [18;25].

Unfortunately, the process of creating new FTZs in Ukraine until 1998 was practically non-existent. This was due to the drawbacks of the proposed projects (seizure of large areas of the Free Economic Zone, attempts to create universal zones to solve many problems at once, the desire to play a difference between the domestic and the world prices to the detriment of the interests of the state, the rate on significant foreign investments, the need to attract significant budgetary resources, etc.), and on the other hand - the disadvantages of the current legislation, when a special law must be adopted by the Verkhovna Rada for each zone. In addition, foreign experience shows that in order to achieve positive results, the functioning 
of the FTZ requires a very long time. In Ukraine, the frequent change of executive power in the center and on the local states did not encourage the formation of the leaders' interest to work in the future.

Only in 1998 there have been some changes in the sphere of implementation of the FTZs. In June 1998, the Decree of the President established the FTZ "Slavutich". FTZ was created before 2010. Privileges: release for the first two years from the date of registration of enterprises from the income tax - provided that the number of workers released from Chernobyl Nuclear Power Plant is not less than 50\%, and their payment fund is not less than $25 \%$ of the general fund payment. In addition, the total amount of investment must not be less than the equivalent of 200 thousand dollars. In the next three years, the company pays $50 \%$ of the current tax rate on profits. Enterprises are also exempted from payment for land, from fees to the Innovation Fund, the Chernobyl Fund and the Employment Fund. Exempt from payment of import duties are on imported raw materials, materials, equipment for the needs of own production (except for excisable goods).

In December 1998, SEZ "Transcarpathia", "Donetsk" and "Azov" were created. Zones in the Donetsk region.SEZ "Donetsk" is located in the south of Donetsk region (area - 466 hectares). FTZ Azov is located in the south of the city of Mariupol (area - 314,8 hectares). On the territory of the Free Economic Zone there were some special preferential customs. By the Resolution of the Cabinet of Ministers of 27.07.98. a list of priority activities were approved. These include: agriculture; mining of coal, oil and gas; non-ferrous metals, sand, clay; development of stone quarries; food, textile, leather, woodworking and paper industry; coke chemistry; production of rubber and plastic products; metallurgy and metal working; production of machines, electric, electronic, transport equipment; production of electric power, gas and water; construction.

In 1999, the Verkhovna Rada adopted the Laws "On the creation of the FTZ of tourist and recreational type" Kurortopolis Truskavets "," On the establishment of the FTZ "Yavoriv" the special economic zone "Yavoriv" was created for the period until January 1, 2020 in the administrative-territorial boundaries of the Yavoriv district of Lviv region (except for the territory of the military training ground and military units). FTZ "Yavoriv" combines a complex production, customs zone and technological park.

In 2000, the relevant laws were adopted on three other FTZs "Mykolaiv", "Porto Franco" (Odessa), "Reni". In total there are currently 12 FTZs. in Ukranie.

The opposition to ASEZ inside and outside of parliament. The Lower House of Parliament then endorsed a draft law on the establishing of the ASEZ (July 2000), not before 
laying down more explicit curbs on the sale of land in Aqaba. In any case, the move was not made with great enthusiasm by legislature. Several deputies had said they were concerned that creating a special zone would undermine Jordan's sovereignty over Aqaba. However, King Abdullah and the Prime Minister assured lawmakers, on different occasions, that Aqaba would remain an indivisible part of Jordan [3]. The government then moved to appoint a commission to manage the transformation of Aqaba into a special economic zone by early 2001 [6]. The ASEZA includes five main branches: "Administration and Finance", "Customs and Revenues", "Investment and Economic Development" as well as "Land, Infrastructure and Services" in addition to "Environmental Regulation and Enforcement". However, this process did not go completely smoothly, and the government was seen as "jumping into deep end" with the ASEZ. Opponents were concerned about a range of issues, including the possibility of heavy Israeli investment, moral issues (the possibility of establishing of casinos, for example) and fears that Aqaba's special status will undermine Jordanian sovereignty over a large area of the country. Nevertheless, alarm bells continued ringing in Jordan over the ambitious government plan for Aqaba into a duty-free special economic zone. Aqaba's proximity to Israel was fanning passions. Aqaba was seen as "very sensitive" as it shares borders with Israel and Saudi Arabia and is the country's only port.

4. The ASEZ management and implementation. The NGO scene in Aqaba was traditionally weak in drawing adherents and consequently in its human capital and institutional resource bases. Most NGOs had budgets that did not exceed few thousand JDs annually and those organizations were dependent on a limited number of volunteers [8]. The integration of NGOs in public development programs - despite the official mandate to co-ordinate with them - remained low before the ASEZ was set up. There were few cases of collaboration between NGOs and the local public authorities. The Aqaba Business and professional Woman Association (BPWA) received a grant from USAID through the Aqaba Technical Assistance Support Program (ATASP) [25]. Through a Small Grants Program, the $\$ 86,000$ donation aims at enhancing programs designed to increase woman's representation and participation in society and in the different economic sectors in the ASEZ. The association started an Internet café for women, to encourage them to benefit from information technology, to widen horizons and enhance their knowledge base. The BPWA, the ASEZ's first and only business woman association, is also laying out an Arabic website and preparing advertising material to spread awareness and publicize the association's activities. 
Administrative and Institutional Issues. The ASEZA also shares power with some service ministers in Amman. For example, the ASEZA is responsible for the provision of healthcare, in accordance with a memorandum of understanding (MoU) signed with the Ministry of Health (MoH).

\section{Lessons \& Conclusions.}

What could be improved and implemented from Jordanian to Ukrainian practice. The main drivers of the government reform explicit or implicit on the ASEZ, the nature of the demand for it, who championed reform, and how the momentum was created, all point to a top-down approach to improved governance; that my after all be the most appropriate approach given by Jordan's present phase of development.

However, this is clearly not to say that the ASEZ project was a result of state policy. If anything the project is certainly donor driven, spearhead by the United States Agency for International Development (USAID). Nonetheless, the ASEZ is championed by the King, and in a system like Jordan's, such a championship appears as "policy."

In any case, the processes by which the ASEZ governance initiative was implemented have proven to be reasonably smooth and successful, despite the complications inherent in transferring authority among institutions that are overseen through nascent, timid democratic practices. Success or failure, and lessons that can be learned from it, are probably still too early to be determined.

Balancing competing interests is important for the success of the ASEZ. These interests comprise human development, regional development, economic growth, environment and the national interest. It is a very tall order. Without doubt, Aqaba has considerable potential; and it could serve as an engine for the rest of the country. Hence, the ASEZA is under tremendous pressure to realize its mandate. There is little room for disappointment, as the government's expectations are high, and the King has invested his own personal prestige in the project.

The partial answer to any governance difficulties that the ASEZ may have experienced or would experience is to co-opt two important groups into the process: the private sector and the people of Aqaba. Of course, these two may overlap. However, for the time being, both are taking a back seat to public sector and external players who, though they are working hard for the promotion and success of the ASEZ, may be turning the whole project into a traditional Jordanian partnership between the higher echelons of the government and foreign actors. 
To allay some of these concerns, it would be interesting to redefine the posts of the ASEZA Commissioners to bring in, formally or otherwise, one person from Aqaba. He (or for that matter she) could play a valuable part in making the development of the ASEZ more attuned to local sensibilities; at worst, such a step would defuse some of the arguments that anti- ASEZ forces have deployed in the past few years.

While creating the FTZ, the state should take into consideration that the zone should be attractive to the investor, first of all, by the level of privileges. Given the competition in the global investment market, the benefits must comply with world standards. If they are lower, the country will be uncompetitive in this market, and if they are higher - you can lose more than get. At the same time, it is impossible to exaggerate the role of tax breaks in the creation of the FTZ, because they do not always ensure economic growth. For solvent investors, privileges are sometimes of secondary importance, unlike small and medium-sized businesses, which always feel the deficiency of free capital. Tax privileges and natural resources can't always replace the lack of modern infrastructure, which is obliged to create a country admitting in its territory. In other words, tax rates should be well-grounded.

Despite of all its capabilities, the FTZs works poorly in Ukraine, mostly due to the lack of a state program of creating free economic zones as an integral part of an active regional policy. An important negative factor is the lack of domestic practical experience in the development of organizational, financial and production mechanisms for the functioning of free economic zones, tax issues, customs regulation, monetary and financial conditions, and zone management. The uncertainty of the status of a free economic zone negatively affects the process of attracting potentially possible investments into the Ukrainian economy.

Specialists also recommend conducting a comprehensive examination of the FTZs' projects. World practice suggests that the expertise of such projects is important, although it costs a lot of money. But this justifies itself, because drawbacks in the initial stage of creating zones can lead to significant monetary-financial and material losses. The work, for example, of the German Advisory Group in Donetsk, showed that the laws on free economic zones in Donetsk region were unattractive to investors. The mechanism provided was too burdened by regulatory measures: for the development of the FTZ, it is necessary to reduce control and to provide more freedom to investors. Moreover the unacceptable difference in the attitude to enterprises of different sizes and industries. German experts believe that the proposed mechanism will lead to the creation of numerous new authorities, but little encouragement of investment. Undoubtedly, reducing tax pressure and removing barriers to foreign trade is attractive. However, in order for these measures to become effective, it is more important that 
they be accompanied by steps to deregulate the market. In world practice, not only the municipal authorities, but also the FTZ administration does not interfere in entrepreneurial activity, which is regulated exclusively by the relevant legislation. In Ukraine everything is different. The authorities try to increase the deductions to the state or local budget through the tax policy, whereas it is necessary to proceed not from the interests of the treasury, but from ensuring the economic incentive of the producer.

Undoubtedly Ukraine has more resource opportunities, such as: natural resources, working capital, and geographical location compared to Jordan, which despite of all the obstacles could implement ASEZ and gradually improve its economy. Jordanian experience proves that the desire of a strong LEADER and his loyal team, despite of the concentration of hot points all around the borders, unstable political relationship with its neighbors, high refugees inflow, definitely led to the deterioration of the economic situation in the country. A large stock of foreign debt, insufficient supplies of water, oil, and other natural resources, high level of unemployment - succeeded in the effective implementation of ASEZ and overcame all the severities. Thus, hopefully this research might inspire the Ukrainian leaders to promote the development of Ukrainian FTZs in order to prosper our economy and improve the standard of living.

\section{References}

1. "Aqaba ASEZ" in the International Herald Tribune, 30 XI 2000

2. "ASEZ Model experience at World Economic Forum" The Star (Amman) 29 VI 2003

3. "European fund to improve Aqaba port" www.arabicnews.com 10 XI 1997

4. "Iraq replaces Aqaba with Syrian, Dubai ports for its imports" www.arabicnews.com 13 X 1998

5. "Jabal Ali seeks development contract for Aqaba Economic Zone” Gulf News, 1 V 2001 "Jordan appoints body to manage the ASEZ" Reuters, 26 IX 2000

6. "Lower House approves the ASEZ draft law" The Jordan Times, 26 VII 2000

7. al Khouri, R “QIZs as a Model for Industrial Development: The Case of Jordan and Its Implications for the Region," Friedrich-Ebert-Stiftung, 2001, www.fes-jordan.org “ASEZ:Perspectives and Prospects" 2001, www.fes-jordan.org

8. Al-Khalidi, S “Jordan King seen appointing new PM to push reforms" Reuters, 17 VI 2000

9. Aqaba Special Economic Zone Website: www.aqabazone.com 
10. Burdette, J "Jordan's New Cabinet is Economy-Minded" US-Arab Tradeline, 23 VI 2000

11. Economic and Business Opportunities," The MENA Economic Conference, Doha, 1997.

12. ESCWA, "Foreign Direct Investment Legislation Reflecting Environmental Concerns in the ESCWA Region," (E/ESCWA/1997/11)

13. Hatter, S “ASEZ: Ambitious Dreams, Conflicting Realities," Friedrich Ebert Stiftung, 2001 - www.fes-jordan.org

14. Jordan Ministry of Planning, "Jordan, a Winning Business Destination: An Overview of

15. Kanaan, T “ASEZ: an Economic Review," Arab Bank Review, vol. 2, no. 2, October 2000.

16. Khouri, Rami “Jordan Governance Paper” World Bank, 2003

17. Levy, M "Eilat, Aqaba is coming after you" Erev: Erev In Eilat, 18 December 2003

18. Majdalani, R "Municipal Governance and Expanded NGOs Role in Selected Countries in the Middle East" paper presented at the 3rd Mediterranean Development Forum, Workshop on "Institutional Reforms and Sustainable Development" Cairo, 2000

19. Mughrabi, H “Jordan's port of Aqaba keen on success" www.arabia.com 9 X 2001

20. Royal Scientific Society, "The Feasibility of Converting Aqaba into a Free Zone," 1994

21. Statement of Chief Commissioner of the ASEZA Aqel Biltaji before the United States House of Representatives International Relations Committee, 24 VII 2002

22. The Services Group, “Aqaba Freeport and Special Economic Zone Study,” 1999.

23. The World Bank - Social and Economic Development Sector Unit Middle East and North Africa Region, Report No. 24425-JO “Jordan Development Policy Review: A Reforming State in a Volatile Region" November, 2002 pp.16-17

24. USAID grant aims at enhancing skills and participation of women in Aqaba" JT, 17 VII 2003

25. ZEF Projekt: „Verbesserung der Wirtschaftsgesetzgebung in arabischen Ländern“ (überregionales Forschungsvorhaben), Januar 2005 